\title{
Rice Husk Ash Incorporation in Container Substrates Effect on Romaine Lettuce Plant Growth
}

\author{
Sreyhor Mot, Sophary Khin, Vibol Peuo, Panha Pok, and Pao Srean* \\ Faculty of Agriculture and Food Processing, National University of Battambang, Battambang \\ 020101, Cambodia. \\ *Corresponding Author: sreanpao@gmail.com
}

\begin{abstract}
Primary substrate components include peat moss, vermiculite, perlite, bark, and compost are commonly-used substrate in horticultural crop production. These substrate components are high cost due to the extreme cost of transportation, fuel for extraction, and processing. Local rice husk ash (RHA) as an alternative substrate component was used to evaluate the growth of Romaine Lettuce plants in response to the application of different incorporations of RHA in container substrates. The test was conducted with a completely randomized design of four RHA treatment, rates at $0 \%, 10 \%, 30 \%$, and $50 \%$ (by vol.), with 10 replicates. The results showed that plant stem elongation increased with decreased incorporations of RHA application. Although the fresh weight of plants (shoot or root) and number of leaves increased with the RHA application, no significant difference for the plant biomass produced (dry weight of root and shoot) between the $30 \%$ and $50 \%$ RHA treatments. The RHA can be used as a local and low cost substrate component; and the incorporation of $30 \%$ (by vol.) RHA in container substrates is a certain amount for lettuce plant growth.
\end{abstract}

Key words: Biochar, container substrate, Lactuca sativa L., organic carbon, soil amendment. Reference to this paper should be made as follows:

Mot, S., S. Khin, V. Peuo, P. Pok, and P. Srean. 2021. Rice Husk Ash Incorporation in Container Substrates Effect on Romaine Lettuce Plant Growth. Agritropica: Journal of Agricultural Sciences. 4(1): 30-37. DOI: https://doi.org/10.31186/Jagritropica.4.1.30-37.

\section{INTRODUCTION}

Rice husk ash (RHA) is an industrial by-product, it produced when rice husk is burnt for energy production to substitute diesel in electricity production to run rice mill machinery. Rice husk accounted for approximately $20 \%$ of paddy production, meaning that about 2 million tons of rice husk were produced annually, while the total paddy production is about 10 million tons per year in Cambodia (MAFF, 2020). About $10 \%$ of the rice husk is estimated to be used for energy production, particularly, for the rice milling sector in the country (Shackley et al, 2012). Very large quantities of the RHA are produced, it becomes a waste problem.
The RHA and rice hush biochar (RHB) are similar components, the RHA contents lower carbon compared to RHB due to uncontrolled burning process (Masulili et al, 2010). Recent research has shown that biochar cane be used as a replacement for commonly-used substrate, e.g. primary substrate components include peat moss, vermiculite, perlite, bark, and compost (Landis et al, 2009; Vaughn et al, 2013; Vaughn et al, 2015). The cost of the commonly-used substrate is high due to the extreme cost of transportation, fuel for extraction, and processing (Landis et al, 2009; Wright \& Browder, 2005). Searching for alternative environmental-friendly and local substrate components are recommended (Carter et al, 2013; 
Huang \& Gu, 2019). The RHA would be an alternative and low cost substrate components for horticultural crop production in Cambodia.

However, the properties of substrate components used and the percentages of biochar in the substrate impact on plant growth (Huang \& Gu, 2019). We hypothesized that different percentages of the RHA in container substrates may impact on lettuce plant growth. The objective of this study was to evaluate the growth of Romaine Lettuce plants in response to the application of different incorporations of RHA in container substrates.

\section{MATERIALS AND METHODS}

\section{Experimental Conditions and Design}

The experiment was conducted in a greenhouse (size - length: $10 \mathrm{~m}$, wide: $8 \mathrm{~m}$, high: $3 \mathrm{~m}$ ) of the National University of Battambang (NUBB), Northwest Cambodia $\left(13^{\circ} 5^{\prime} 6.95^{\prime \prime} \mathrm{N}, 103^{\circ} 13^{\prime} 15.25^{\prime \prime} \mathrm{E}\right)$, from November, 2020 to January, 2021. Air temperature, relative humidity and light density during growing condition were daily measured at $8 \mathrm{AM}, 12 \mathrm{PM}$ and $4 \mathrm{PM}$ inside the greenhouse, see Fig. 1 for average daily temperature, relative humidity and light density recorded.
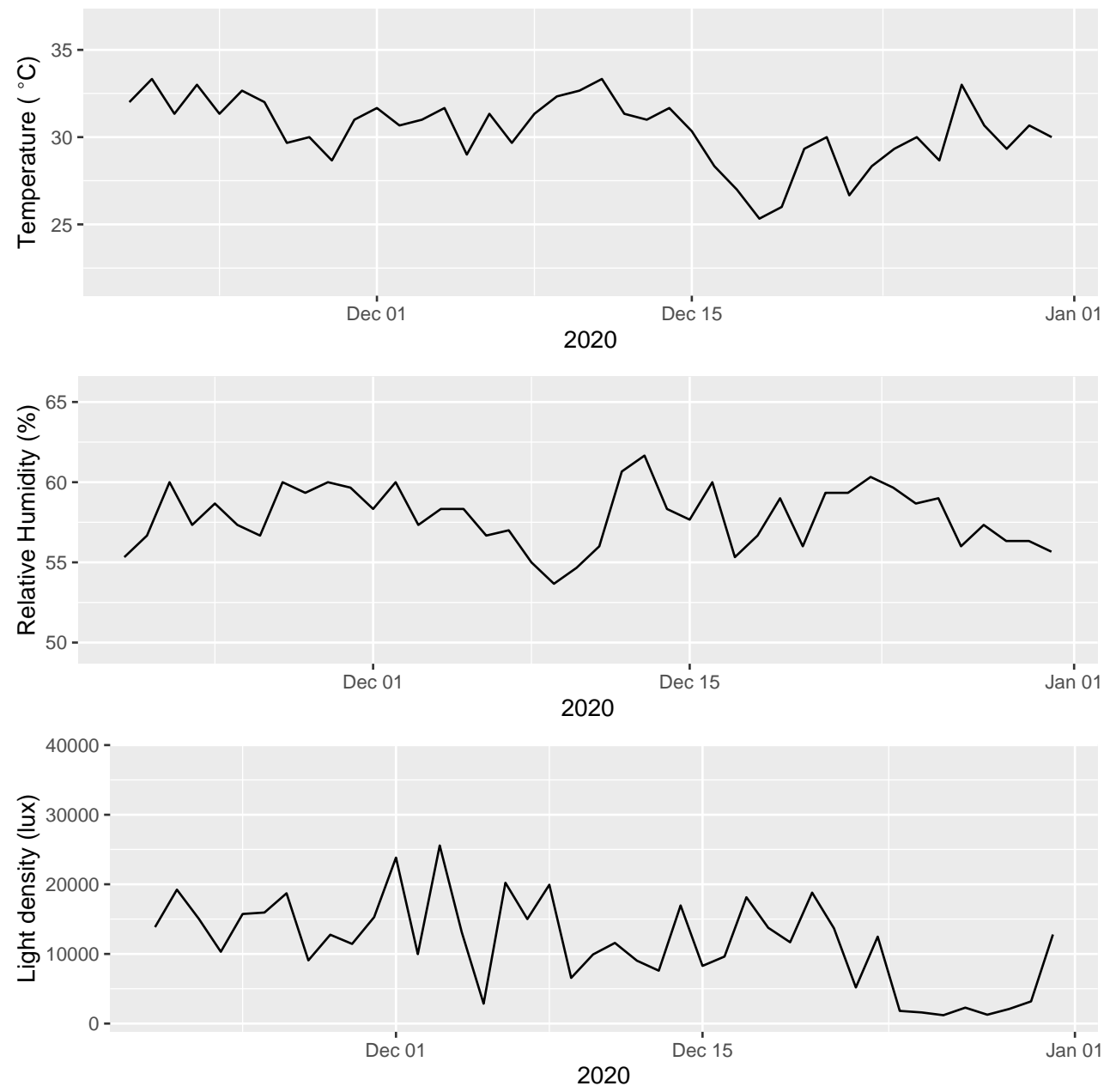

Fig. 1: Average daily temperature, relative humidity and light density measured at 7 AM, 12 PM and 4 PM, over the growing conditions inside the greenhouse. 
A completely randomized design was used with four different treatments, with 10 replications (single pant per pot) for each treatment (Fig. 2). A mixing of $90 \%$ (by vol.) soil with $10 \%$ composting cow manure as basis, incorporated with, $0 \%$ RHA for control treatment, and $10 \%$, $30 \%$, or $50 \%$ RHA (by vol.) for the other three treatments.

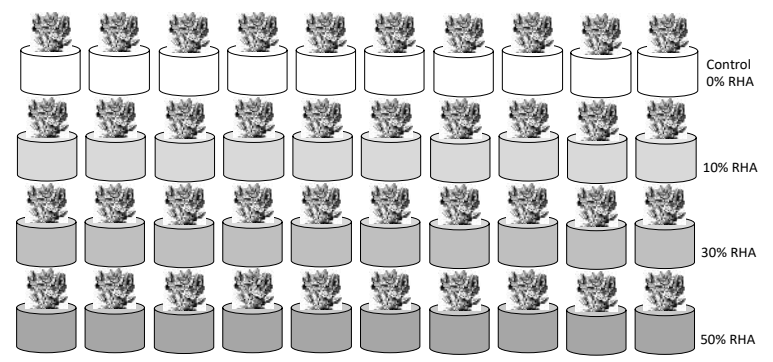

Fig. 2: Layout of the experimental design for the application of different incorporations of rice husk ash (RHA) in container substrates for the Romaine lettuce plant cultivation in the greenhouse.

The RHA used in this study was a by-product after energy production to substitute diesel in electricity production to run rice mill machinery in Battambang; it contents: $77.89 \% \mathrm{SiO}_{2}, 39.81 \% \mathrm{C}, 1.20 \%$ $\mathrm{K}_{2} \mathrm{O}, 0.70 \% \mathrm{~N}, 0.56 \% \mathrm{P}_{2} \mathrm{O}_{5}, 0.47 \% \mathrm{CaO}$, 0.44\% $\mathrm{Fe}_{2} \mathrm{O}_{2}, 0.29 \% \mathrm{MgO}:, 0.16 \% \quad \mathrm{Al}_{2} \mathrm{O}_{2}$ :, and $0.01 \% \mathrm{Na}_{2} \mathrm{O}$. The soil was classified as Brown hrydromorphic soil group (Crocker 1962), and collected at the experimental field of NUBB, contents $50 \%$ clay, and $\mathrm{pH}$ : 6.02. Black polyethylene plant grow pots, with size of $20 \mathrm{~cm}$ diameter and $20 \mathrm{~cm}$ heigh were used as container of the substrates.

Green Romaine Lettuce (Lactuca sativa L. var. longifolia) was selected for this experiment as an example of leafy vegetable crops. The lettuce seeds were produced by the Sen Vàng Seeds Co. Ltd, Vietnam (purity: 98\%, germination rate: $85 \%$, moisture: $10 \%$ ), were sown on trays containing mixed soil and composting cow manure (2:1) then kept them under the net house and watering twice a day. Similar size the lettuce seedlings with 2 - 3 leave per plant, were transplanted in the container substrates when they were at 2 weeks old, one plant each container substrate. The plants were watered twice a day (at 7 AM and 4 PM). Two weeks after transplanting, 80g Urea was dissolved into 10L water then applied once to all plants (2g Urea per plant).

\section{Data Collection and Statistical Analysis}

To compare plant growth and development in each treatment, fresh and dry weight of shoot and root per plant were measured at the end of the experiment (42 days after transplanting). For fresh weight, shoot and root per plant were weighted after cutting then kept them in a hot air oven (Model 500; Memmert, Buchenbach, Germany) at $85^{\circ} \mathrm{C}$ for 48 hours, and then incubated in desiccators before measurement of their dry-weight.

To test the significance of difference in means of each variable for multiple groups, one-way analysis of variance or the Kruskal-Wallis test (Kruskal \& Wallis, 1952) was used due to the data were unnormal distribution. Tukey's test (Tukey, 1949) was applied to compare all possible pairs of mean for each variable. All pairwise comparisons using least significant difference at $a=0.05$. All statistical analyses were performed with the $\mathrm{R}$ statistical software, version 3.6.3 ( $\mathrm{R}$ Core Team, 2020); and the plots were performed using 'ggplot2' R package (Wickham, 2011). To visualize correlations between all pairwise combinations of the variables included plant height, number of leaves, shoot and root dry weights, and amount of RHA used, bivariate relationships were analysed using Pearson's correlation coefficient for 
numerical variables by performing correlation matrix using scatter plots in the 'Performance Analytics' R package (Carl and Peterson 2010).

\section{RESULTS AND DISCUSSION}

Growth of the lettuce plants was found to be affected by RHA application (Fig. 3). For both plant shoot and root grew better when the higher amounts of RHA were applied, while the plant growth in the $10 \%$ RHA treatment was not significantly different comparing with those in the control group for both the shoot and root. The greatest growth was found in the 50\% RHA treatment for the fresh weight of plant shoot and root, whereas their dry weights were not significant different between the $30 \%$ and $50 \%$ RHA treatments, indicating that the
50\% RHA container substrate would provide more nutrients and water availability for plant growth.

The Pearson's correlation matrix plot (Fig. 4) showed that the dry weight of plant shoot, root, or number of leaves were significantly positive correlated with the amount of RHA applied, whereas the plant height was negatively correlated with the RHA application; showed that the RHA incorporates to make a better container substrate for a better root growth, allowing plants to take more nutrients and water for increasing number of leaves and leaf expansion, rather than stem elongation. The longer stem length with less leaves were observed in the container substrates with the $10 \%$ and $30 \%$ RHA treatments (by vol.).
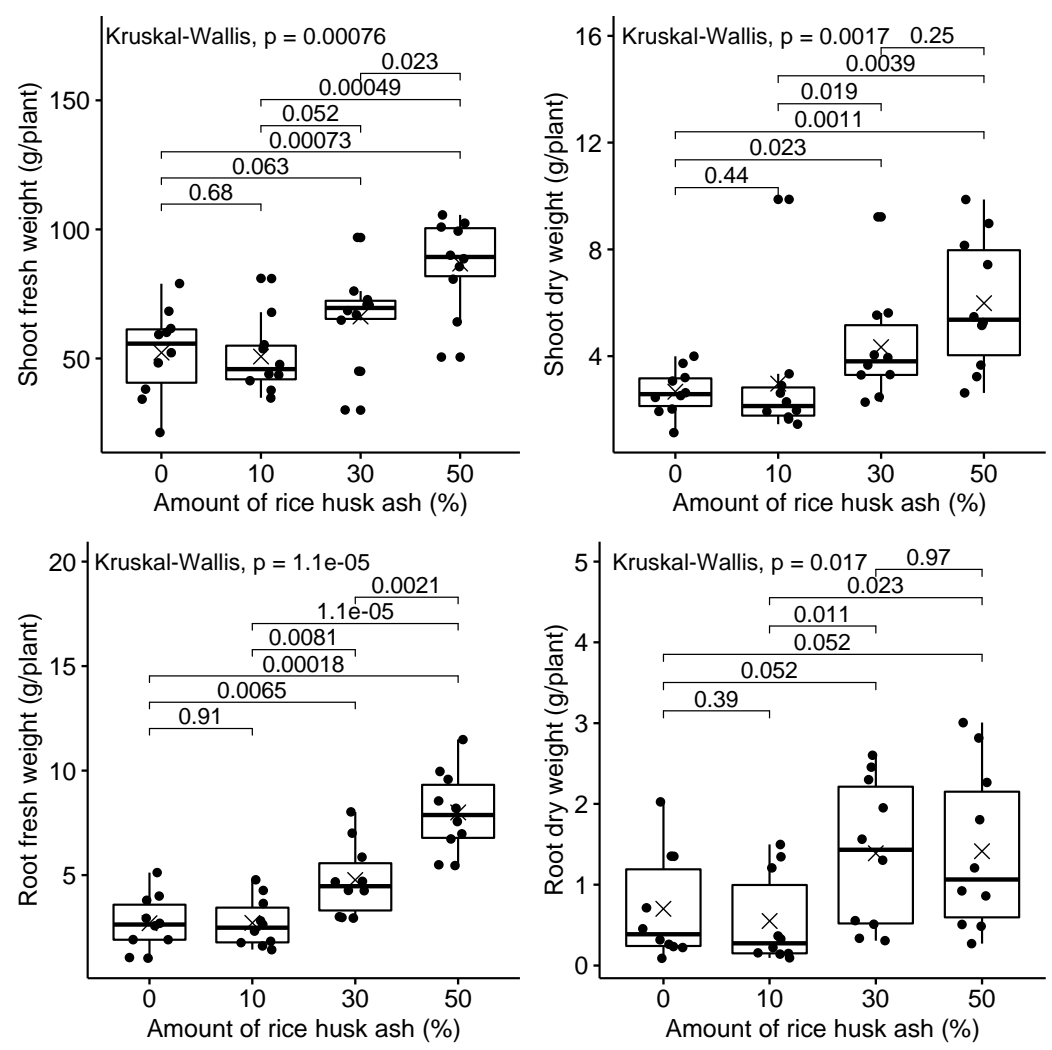

Fig. 3: Boxplot showing all pairwise comparisons of mean for the fresh and dry weight of shoot and root per plant in each treatment. Note: the black dots were individual data point $(n=10)$; the crosses indicated mean value of each treatment group. 
The RHA incorporation in container substrates improve container capacity allowed lettuce plants to take more nutrients and water for the growth. The $30 \%$ (by vol.) RHA incorporation showed a better growth of letter plants in biomass production for shoot and root, this would be a certain RHA amount for container substrate incorporation. Carter et al (2013) showed that the incorporate of RHA (50 - 150 g) mixed with lake sediment (12.56 g), compost (25.12 g) and liquid compost application (by weight per $1 \mathrm{~kg}$ substrate) used for container substrate could increase shoot and root growth of lettuce plants.

The RHA is an industrial byproduct, due to uncontrolled burning process, the produced RHA has lower carbon content compared to rice husk biochar, whereas it has the same function for improvement of container substrate capacity (Masulili et al, 2010). The incorporation of $50 \%$ (by vol.) biochar with peat was found would increase peat substrate due to increased micropores after biochar incorporation (Méndez et al, 2015). Biochar incorporation could improve container substrates including: physical properties, e.g. increased bulk density, total porosity, air space and container capacity (Dumroese et al, 2011; Tian et al, 2012; Cao et al, 2014; Fan et al, 2015; Rusdi, et al 2019), and chemical properties, e.g. $\mathrm{pH}$, electrical conductivity, cation exchange capacity (Yamato, et al 2006; Li et al, 2013; Carlile et al, 2015; Lawrinenko \& Laird, 2015) for plant growth enhancement. The RHA also contents inorganic nutrients that can serve as a fertilizer to biofortify crops with plant essential nutrients included $\mathrm{N}, \mathrm{K}, \mathrm{P}, \mathrm{Si}, \mathrm{Ca}$, $\mathrm{Fe}, \mathrm{Mg}$, etc. (White \& Brown, 2010; Singha et al, 2019).

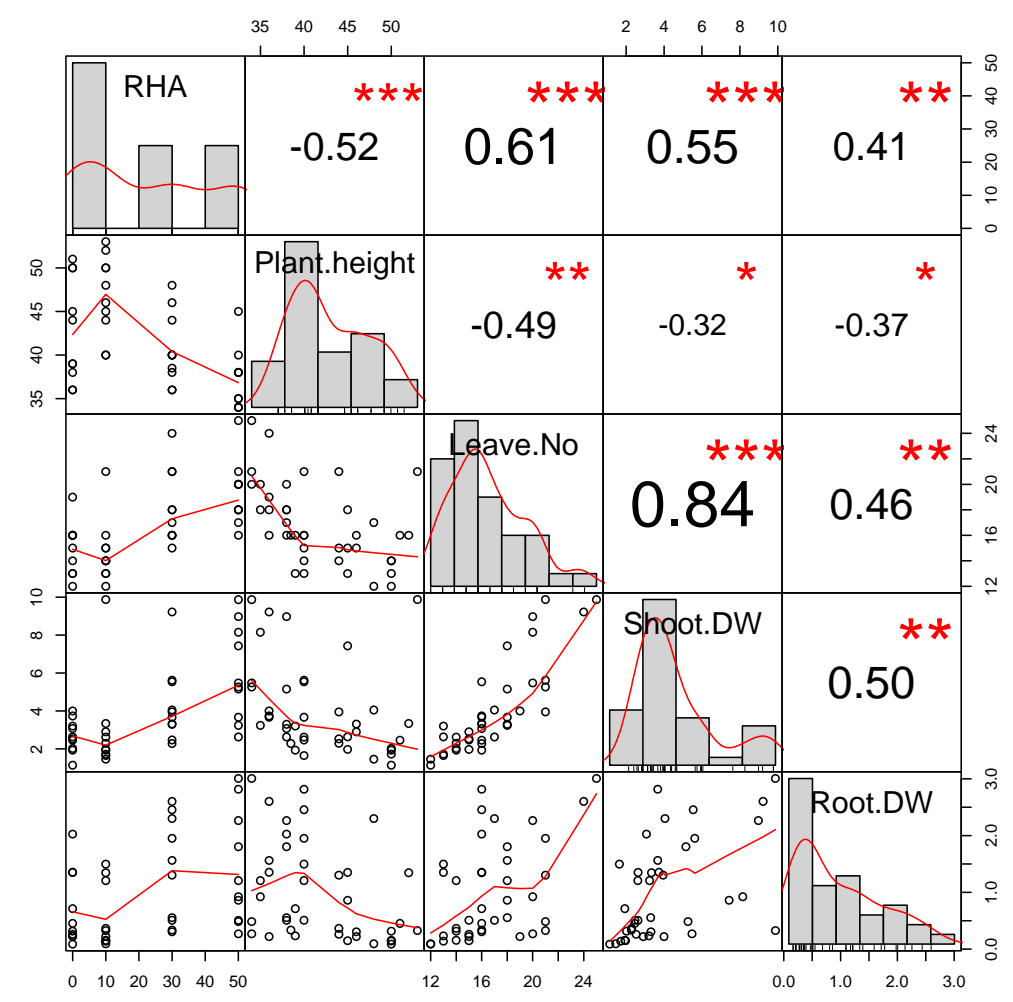

Fig. 4: The Pearson's correlation matrix of the plant growth variables and RHA applied. Note: RHA: rice husk ash (\%; by vol.), Plant.height: maximum plant height $(\mathrm{cm})$, Leave.No: number of leaves per plant, Shoot.DW: dry weight of plant shoot (g/plant), Root.DW: dry weight of plant root (g/plant); ${ }^{*} \mathrm{P}<0.05 ;{ }^{* *} \mathrm{P}<0.01$; ${ }^{* * *} \mathrm{P}<$ 0.001 . 
Biochar application can increase $\mathrm{pH}$, available water content, and influx of nutrients stimulating microbial communities and increasing microbial biomass (Saito, 1990; Warnock et al, 2007; Ezawa, 2002).

\section{CONCLUSION}

The incorporation of RHA application impacted on growth of the lettuce plants. Plant stem elongation increased with decreased RHA application. The fresh weight of plants (shoot and root) and number of leaves increased with the percentage of RHA application, whereas the plant biomass (dry weight of root and shoot) produced similarly in either the $30 \%$ or $50 \%$ (by vol.) RHA applications. Higher incorporation of the RHA in container substrates allow plants absorb more water. The RHA can be used as a substrate of local and low cost components, and the incorporation of $30 \%$ (by vol.) RHA in container substrates is a certain amount for lettuce plant growth.

\section{ACKNOWLEDGEMENTS}

This research was supported by the Sub-project on 'Innovative Farming Systems for Improved Nutrient and Income in NW Cambodia' - IFINI (ref. HEIP-UBB-SGA\#01) of the 'Higher Education Improvement Project' - HEIP. We appreciate the input of two anonymous reviewers who gave their valuable time to help us improve our manuscript.

\section{REFERENCES}

Cao, C. T. N., Farrell, C., Kristiansen, P. E. \& Rayner, J. P. (2014). Biochar makes green roof substrates lighter and improves water supply to plants. Ecological Engineering, 71, 368-74.
Carl, P. \& Peterson, B. G. (2010). PerformanceAnalytics:

Econometric tools for performance and risk analysis. $\mathrm{R}$ package version 1.0.2.1.

Carlile, W., Cattivello, C., Zaccheo, P. (2015). Organic growing media: Constituents and properties. Vadose Zone Journal, 14, 1-13.

Carter, S., Shackley, S., Sohi, S., Tan, B. S. \& Haefele, S. (2013). The empact of biochar application on soil properties and plant growth of pot grown lettuce (Lactuca sativa) and cabbage (Brassica chinensis). Agronomy, 3, 404-418.

Crocker, C. D. (1962). Exploratory Survey of the Soilsof Cambodia, Royal Cambodian Government Soil Commission and U.S. Agency for International Development, Phnom Penh, Cambodia.

Dumroese, R. K., Heiskanen, J., Englund, K. \& Tervahauta, A. (2011). Pelleted biochar: Chemical and physical properties show potential use as a substrate in container nurseries. Biomass Bioenergy, 35, 2018-2027.

Ezawa, T., Yamamoto, K. \& Yoshida, S. (2002). Enhancement of the effectiveness of indigenous arbuscular mycorrhizal fungi by inorganic soil amendments. Soil Science and Plant Nutrition, 48, 897-900.

Fan, R., Luo, J., Yan, S., Zhou, Y. \& Zhang, Z. (2015). Effects of biochar and super absorbent polymer on substrate properties and water spinach growth. Pedosphere, 25, 737-748. 
Huang, L. \& Gu, M. (2019). Effects of biochar on container substrate properties and growth of plant a review. Horticulture, 5 (1), 14.

Kruskal W. H. \& Wallis W. A. (1952). Use of ranks in one-criterion variance analysis. Journal of the American

Statistical Association. 47 (260): 583-621.

Lawrinenko, M. \& Laird, D.A. (2015). Anion exchange capacity of biochar. Green Chemistry, 17 (9), 4628-4636.

Landis, T.D. \& Morgan, N. (2009). Growing Media Alternatives for Forest and Native Plant Nurseries. In National Proceedings: Forest and Conservation Nursery Associations-2008. Proceedings RMRS-P-58; Dumroese, R.K., Riley, L.E., Eds.; US Department of Agriculture, Forest Service, Rocky Mountain Research Station: Fort Collins, CO, USA; pp. 26-31.

Li, X., Shen, Q., Zhang, D., Mei, X., Ran, W., Xu, Y. \& Yu, G. (2013). Functional groups determine biochar properties ( $\mathrm{pH}$ and EC) as studied by two-dimensional 13c nmr correlation spectroscopy. PLOS ONE, 8, e65949.

MAFF. (2020). Annual Report: Ministry of Agriculture, Forestry and Fisheries (MAFF). Phnom Penh, Cambodia.

Masulili, A., Utomo, W. H. \& Syechfani, M. S. (2010). Rice husk biochar for rice based cropping system in acid soil 1 . The characteristics of rice husk biochar and its influence on the properties of acid sulfate soils and rice growth in West Kalimantan, Indonesia. Journal of Agricultural Science, 2 (1), 39-47.

Méndez, A., Paz-Ferreiro, J., Gil, E. \& Gascó, G. (2015). The effect of paper sludge and biochar addition on brown peat and coir based growing media properties. Scientia Horticulturae, 193, 225230.

Rajkovich, S., Enders, A., Hanley, K., Hyland, C., Zimmerman, A. R. \& Lehmann, J. (2012). Corn growth and nitrogen nutrition after additions of biochars with varying properties to a temperate soil. Biology and Fertility of Soils, 48 (3), 271-284.

R Core Team. (2020). R: A language and environment for statistical computing. $\mathrm{R}$ Foundation for Statistical Computing, Vienna, Austria.

URL

https://www.Rproject.org.

Rusdi, I. A., Rauf, S., \& Hidayat, B. (2019). Application of biochar from palm oil plants residues on physical properties of Ultisol. Agritropica: Journal of Agricultural Sciences, 2(2), 93-97.

Shackley, S., Carter, S., Knowles, T., Middelink, E., Haefele, S., Sohi, S., Cross, A. \& Haszeldine, S. (2012). Sustainable gasificationbiochar systems? A case-study of rice-husk gasification in Cambodia, Part 1: Context, chemical properties, environmental and health and safety issues. Energy Policy, 42, $49-58$. 
Saito, M. (1990). Charcoal as a microhabitat for VA mycorrhizal fungi, and its practical implication. Agriculture, Ecosystems $\mathcal{E}$ Environment, 29 (1-4), 341-344.

Singh, R., Srivastava, P., Singh, P., Sharma, A. K., Singh, H., \& Raghubanshi, A. S. (2019). Impact of rice-husk ash on the soil biophysical and agronomic parameters of wheat crop under a dry tropical ecosystem. Ecological indicators, 105, 505-515.

Tian, Y., Sun, X., Li, S., Wang, H., Wang, L., Cao, J. \& Zhang, L. (2012). Biochar made from green waste as peat substitute in growth media for Calathea rotundifola cv. Fasciata. Scientia Horticulturae, 143, 15-18.

Tukey, J. (1949). Comparing Individual Means in the Analysis of Variance. Biometrics, 5 (2), 99-114.

Vaughn, S. F., Kenar, J. A., Eller, F. J., Moser, B. R., Jackson, M.A. \& Peterson, S. C. (2015). Physical and chemical characterization of biochars produced from coppiced wood of thirteen tree species for use in horticultural substrates. Industrial Crops and Products, 66, 44-51.

Vaughn, S. F., Kenar, J.A., Thompson, A. R. \& Peterson, S. C. (2013).
Comparison of biochars derived from wood pellets and pelletized wheat straw as replacements for peat in potting substrates. Industrial Crops and Products, 51, 437-443.

Warnock, D. D., Lehmann, J., Kuyper, T. W. \& Rillig, M. C. (2007). Mycorrhizal responses to biochar in soil-concepts and mechanisms. Plant Soil, 300 (1), 9-20.

Wickham H. 2011. 'ggplot2'. Wiley Interdisciplinary Reviews: Computational Statistics, 3(2): 180185.

White, P. J. \& Brown, P. H. (2010). Plant nutrition for sustainable development and global health. Annals of Botany, 105 (7), 10731080.

Wright, R. D. \& Browder, J. F. (2005). Chipped pine logs: A potential substrate for greenhouse and nursery crops. HortScience, 40 (5), 1513-1515

Yamato, M., Okimori, Y., Wibowo, I. F., Anshori, S. \& Ogawa, M. (2006). Effects of the application of charred bark in Acacia mangium on the yield of maize, cowpea, peanut and soil chemical properties in south Sumatra, Indonesia. Soil Science and Plant Nutrition, 52, 489-495. 